\title{
Farmers' Perspective about Organic Manure Production and Utilization in Dakshina Kannada, India.
}

\author{
Pierre Dukuziyaturemye* ${ }^{* 1}$, Celestin Banamwana ${ }^{1}$, Prashantha Naik ${ }^{2}$ \\ ${ }^{1}$ College of Medicine and Health Sciences, University of Rwanda Po Box 3286 Kigali Rwanda \\ ${ }^{2}$ Department of Biosciences, Mangalore University, Mangalagangothri - 574199 \\ * Corresponding Author \\ dukuzegift@gmail.com, +250781575845
}

\begin{abstract}
The perception and utilization of organic manure have all along been critical, due to the socioeconomic and demographic factors among farmers of different parts of the world including India. A study aimed to explore factors affecting farmer's perception about organic manure production and its utilization in Dakshina Kannada. A questionnaire-based survey was used to collect data from farmers and bears quantitative data. This data shows that the $3.2 \%$ of farmers adopted farming activities for more than 30 years, and the experience acquired has influenced the knowledge and perceptions on utilization of organic manure. It was found that $86 \%$ of males and females positively enjoyed producing organic manure, while $14 \%$ had a negative attitude towards the practice. The core factor influencing farmers to produce organic manure from municipal solid wastes was high yield/crop production which accounted for $16.1 \%$ of all respondents. The study indicates that the attitude and willingness to use organic manure from organic waste were high among the farmers of Dakshina Kannada, India. Therefore, an approach that can get the farmers involved in organic manure production using organic wastes could be implemented to inform good practices.
\end{abstract}

Keywords: Wastes, agriculture, attitude, fertilizer, wastes management, small farmers

\section{Introduction}

Owing to the size of the urban population, coupled with the high consumption lifestyles of that community, India is ranked among the worlds top 10 countries that generate high volumes of Municipal solid waste (MSW). This is estimated at 188,500 tons per day (Shitala, 2014). An investigation on solid waste in major cities of India, has revealed that degradable organic matter accounts for about 51\% (Annepu, 2012). The collected items are often dumped on open land, or used for landfilling, and this leads to severe environmental hazards (Du et al. 2014). Although incineration is applied for waste disposal, it releases toxic gases into the atmosphere (Kim and Kim, 2010). The best principle of any waste management system aims to maximize economic benefit, minimize the cost of waste disposal and maintain environmental standards.

It is noted that most people think of organic manure first, when it comes to municipal solid waste management. It is well known that the conversion of solid waste to organic manure is economically an effective way of managing MSW generated from households and agricultural activities. This is one of the best practices in finding the solution to severe deterioration of soil organic matter and crop productivity 
(Lal, 2015). It was found ou that the use of organic fertilizers reduces considerably the quantity of the waste that ends up in landfills (Lim et al. 2016). It also reduces the usage of inorganic fertilizers (Lim et al. 2015). It was also revealed that continuous use of manure in the soil provides large amounts of macronutrients such as nitrogen $(\mathrm{N})$, phosphorus $(\mathrm{P})$, potassium $(\mathrm{K})$, calcium, and magnesium to the soil (Ginting et al 2003, Watts et al., 2010). Through vermicomposting and pit composting, organic waste can be recycled to give a beneficial end product containing macro and micronutrient elements that have a positive effect on soil and are crucial for plant growth and production.

A study carried out in Nigeria has indicated that bio-organic input has been neglected, with common utilization of mineral fertilizer among farmers (Ukoje and Yusuf, 2013). Furthermore, many studies have been conducted on the application of organic materials to the soil like yard waste compost (Antonious, 2003), straw (Kucharski et al., 2000), manure (Moore et al., 1998), wood products (Stratton and Rechcigl, 1998), chipped wood from twigs (Lalande, 1998). However, there is still a controversy on the scale of demand for organic manure and how many people, particularly farmers, are ready to participate in organic manure production. This study is intended for evaluating the farmers' perception on decentralized organic manure production and utilization, as an effective strategy in solid waste management.

\section{Materials and Methods}

\section{a. Description of the study area}

Dakshina Kannada is a coastal district in the state of Karnataka (India), with an area of 4,861 km2, sheltered by the Western Ghats in the East and surrounded by the Lakshadweep Sea in the West. It is located on $12^{\circ} 52^{\prime} 12^{\prime \prime} \mathrm{N}, 74^{\circ} 52^{\prime} 48^{\prime \prime} \mathrm{E}$ (Latitude: $12^{\circ} 27^{\prime}$ and $13^{\circ} 58^{\prime}$ North Latitude; Longitude: $74^{\circ} 35^{\prime}$ and $74^{\circ} 4^{\prime}$ East Longitude)

\section{b. Research Design}

A questionnaire-based survey to find out the assertiveness of farmers regarding the implementation of domestic waste recycling, was carried out from July 2018 to January 2019. The study employed quantitative methods.

\section{c. Sampling procedure}

The probability sampling procedure involves selecting a sample in such a way that all the elements in the population have the same chance of being selected (Crano et al., 2014). Two taluks out of five were selected randomly, and the study was confined to Mangaluru and Belthangady taluks, where a sample of 250 people were used as respondents.

\section{d. Data Collection procedure}

The quantitative data were collected using questionnaire among farmers. The questionnaire comprised of 50 questions (closed-ended questions) that was distributed to farmers.

\section{e. Data processing and analysis}

According to Durbin (2004), in some situations, not all data can be presented in their entirety. Hence, the contents of tables are usually percentages, frequencies or some summary statistical measures. 
Therefore, data were processed, and findings were presented using tables, for which recommendations and conclusions were made. Graphs and pie charts were used to present the findings from the questionnaires and observation. The analysis of data was done using Microsoft Excel

\section{f. Ethical considerations}

According to Yip et al. (2016), ethical considerations involve measures to avoid future conflict around individuals' rights to privacy, the undesirability of manipulation, confidentiality, consent of respondents, plagiarism and so on. Individual's rights to privacy and confidentiality have been addressed by keeping anonymous all respondents. The consent of each respondent was sought before completing the questionnaire. The respondents were briefed on the purpose of the research work, and asked to freely give correct answers. To avoid plagiarism, I followed the good rule-of-thumb consisting of properly mentioning the sources of information either by making citations or paraphrasing the author and mentioning $\mathrm{him} / \mathrm{her}$.

\section{Data presentation and Discussion}

\subsection{Demographic information of respondents}

Socio-economic characteristics are visualized to influence farmers' manure production decision as well as their overall utilization efficiency. In this study, the socio-economic characteristics considered are gender and type of farmer, farm size, and years of farming experience.

Table 1: Gender and type of farmers $(\mathrm{N}=250)$

\begin{tabular}{llll}
\hline Social perspective & Gender & Total \\
\cline { 2 - 4 } & Male farmers & Female farmers \\
\hline Intensive farmers & $54(21.6 \%)$ & $45(18 \%)$ & $99(39.6 \%)$ \\
\hline Subsistance farmers & $101(40.4 \%)$ & $50(20 \%)$ & $151(60.4 \%)$ \\
\hline Total & $155(62 \%)$ & $95(38 \%)$ & $250(100 \%)$ \\
\hline
\end{tabular}

Considering gender, the results showed that the majority of the respondents $(62 \%)$ were male, while $38 \%$ were female farmers. The big number of males in the study could be associated with the sociocultural background of the community. Taking into account the type of farmers, the results revealed that intensive farmers were $39.6 \%$ while subsistence farmers were $60.4 \%$. Maity and Tripathy (2004) categorized farmers into three types: farmers who mostly follow the indigenous knowledge and technology, those with small to medium-sized holdings, and farmers who have responded to market demands. 


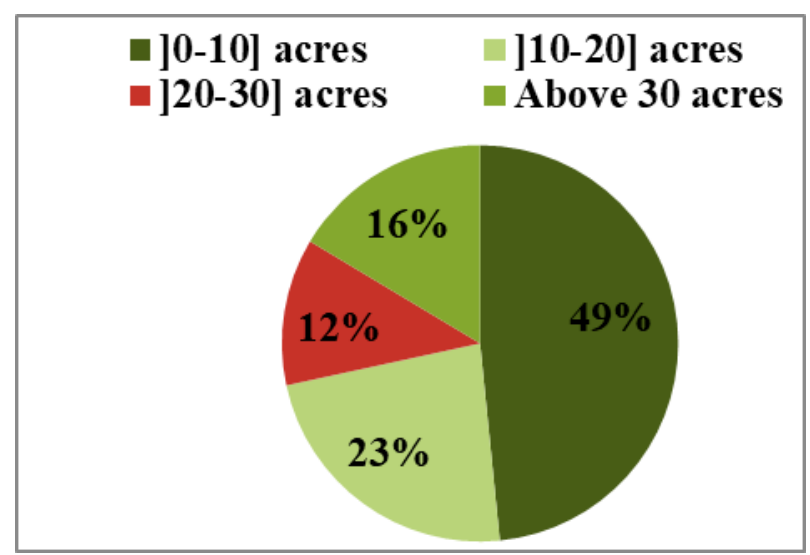

Figure 1: Farm size possession

Based on farm size, the respondents were distributed into three categories namely, small farm (020 acres), medium farm (21-30 acres) and large farm (above 30 acres). The consolidation of these findings revealed that $71.6 \%$ of farmers fall into the small farm category, $12 \%$ were in the medium category, and $16.4 \%$ in the large category. The implication of farm size holding in this study revealed that more than half of the respondents were small scale farmers based on the above-mentioned classification of small-scale farms by Chikezie et al. (2012). The results are also in concordance with the findings of Carletto et al., (2011) about the relationship between agricultural productivity and plot area among small agricultural producers.

The determination of farmers' ability to make effective farming practice decisions is linked to their and skills and experience.

Table 2: Farmers' experience in agriculture

\begin{tabular}{lll}
\hline Time Period & Frequency & Percentage \\
\hline $\mathbf{0 - 1 0}$ years & 90 & 36 \\
\hline $\mathbf{1 1 - 2 0}$ years & 100 & 40 \\
\hline $\mathbf{2 1 - 3 0}$ years & 52 & 20.8 \\
\hline Above 30 years & 8 & 3.2 \\
\hline Total & 250 & 100 \\
\hline
\end{tabular}

The results showed that about $36 \%$ of the respondents had less than 10 years in farming; $40 \%$ of respondents had been practicing agriculture for 11 to 20 years; $20.8 \%$ of respondents had experienced farming for 21 to 30 years, and $3.2 \%$ had adopted farming activities for more than 30 years. The experience in farming is significantly associated with the adoption of certain farm practices like manure production and utilization, and could give an indication of the extent of practical knowledge applied.

\subsection{Application of Fertilizer}

The secret towards rapid agricultural progress in underdeveloped countries lies much more in agricultural extension, use of fertilizers and new seeds and appropriate pesticides, as well as a constant water supply, rather than in altering the size of the farm, introducing machinery, or getting rid of middle men in the marketing process. Table 3 below shows the farmers' engagement in using fertilizer for sustainable agriculture. 
Table 3: Use of organic manure among farmers

\begin{tabular}{lll}
\hline Statement & Frequency & Percentage \\
\hline Yes & 230 & 92 \\
\hline No & 20 & 8 \\
\hline Total & 250 & $250(100)$ \\
\hline
\end{tabular}

The results revealed that the majority of respondents $(92 \%)$ used fertilizers in agricultural activities, while $8 \%$ did not. This proved that the application of fertilizers in farming has significant positive effects on crop yields in the study area. Although the majority of farmers were using fertilizers, several studies have revealed some challenges in fertilizer application. For instance, Okoboi and Barungi (2012) in their study found out that farmers do not use fertilizers because of lack of funds and knowledge. Also, Abdoulaye and Sanders (2005), Kelly (2006) and Morris et al. (2007) found that farmers lack adequate knowledge and skills required for fertilizer utilization.

\subsection{Type of Organic Manure frequently used by farmers}

It is well known that organic fertilizers are crucial in the agricultural sector because they have positive effects on soil by supplying the required macro- and micro-nutrients to the plants, without deteriorating the environment. The figure below shows the frequency at which the various organic manure sources are used by farmers in Dakshina Kannada District.

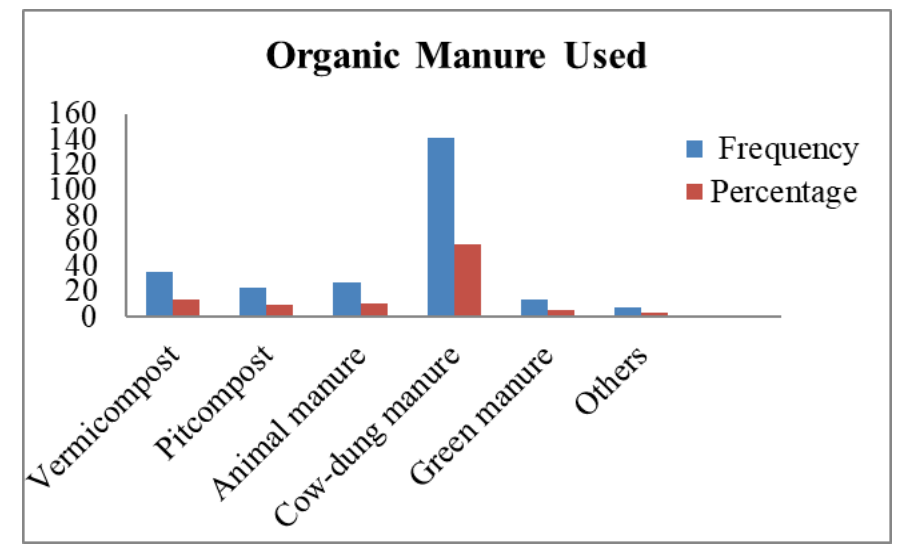

Figure 2: Distribution of Respondent by Organic manure frequently used

The types of organic manure used by farmers are the vermicompost which accounted for $14.1 \%$, pit compost $9.3 \%$, animal manure $10.9 \%$, cow dung manure $56.9 \%$, green manure $5.6 \%$, and other types of organic manure with $3.2 \%$. The results showed that cow dung manure was the most frequently used type of organic manure, probably due to the large number of cattle available in many families, as well as its nutrient content, compared to other manures. Vermicomposting took the second position, probably because it is the easiest to produce and utilize. Research has also shown that vermicompost produced from organic waste is effective in reducing pathogenic microorganisms (Garg et al., 2006; Arancon et al., 2004; Kumar and Yadav, 2011). For pit compost manure, apart from its nutrient content, it's production has proved to be fast, easy, cheap, requiring less water, and less investment (Inckel et al., 2005). Also, it is appropriate where daily organic waste generation is high among Dakshinna Kannada communities. With suitable usage, it has been revealed that animal manure provides a high content of macro- and 
micro-nutrients for plants growth, it is environment- friendly (Moral et al. 2009), and an appropriate way of destroying pathogens (Grewal et al. 2006). Fageria, (2007) found that green manuring improves the soil's physical, chemical and biological properties, and this subsequently affects crop yield positively .

\subsection{Factors inspiring farmers to produce organic manure}

Organic manure must be produced in sufficient quantities to supply the required nutrients to the soil and to the crops. The farmer's decision to adopt organic manure production is not necessarily based on individual profit, but also on the benefits of the society as a whole. The farmers are influenced by various factors associated with their socioeconomic status, culture, weather and climate, the farmer's personal character, knowledge and skills, experience, technology, motivation, and market demand among others. Table 4 shows the factors that would make farmers adopt organic manure production, particularly in Dakshina Kannada District.

Table 4: Factors inspiring farmers to produce organic manure

\begin{tabular}{lll}
\hline Factors & Number of respondents & Percentage \\
\hline High yield & 40 & 16.1 \\
\hline Easy production & 41 & 16.5 \\
\hline Interest & 31 & 12.4 \\
\hline Low expenditure & 23 & 9.2 \\
\hline Availability of raw material & 38 & 15.3 \\
\hline Environment - friendly & 18 & 7.2 \\
\hline All these & 58 & 23.3 \\
\hline Total & 249 & 100 \\
\hline
\end{tabular}

The factors influencing farmers to produce organic manure from municipal solid waste were high yield/crop production accounting for $16.1 \%$ of all respondents and ease of the production process (technology) of organic manure which was $16.5 \%$. The interest of farmers accounted for $12.4 \%$, low expenditure $9.2 \%$, availability of raw materials (biodegradable waste) $15.3 \%$, environment-friendliness $7.2 \%$. It was found that $23.3 \%$ of respondents declared that all the above factors can influence farmers to produce organic manure. The farmers can produce organic manure because it improves soil quality, provides conditions that are suitable for diverse living organisms, improve the health of the soil, and leading to better crop yield. (Zhang et al. 2016).

\subsection{Raw material/waste used for organic manure production}

Organic waste disposal is a major problem and the conversion of this material into organic fertilizer is a desirable option vis à vis the severe depletion of soil organic matter and declining crop productivity (Lal, 2015; Sudharmaidevi et al., 2017). It is known that fertilizers from organic waste have a positive effect on food quality, and that many suitable types ofwaste can be used to produce it, as shown in the figure below. 


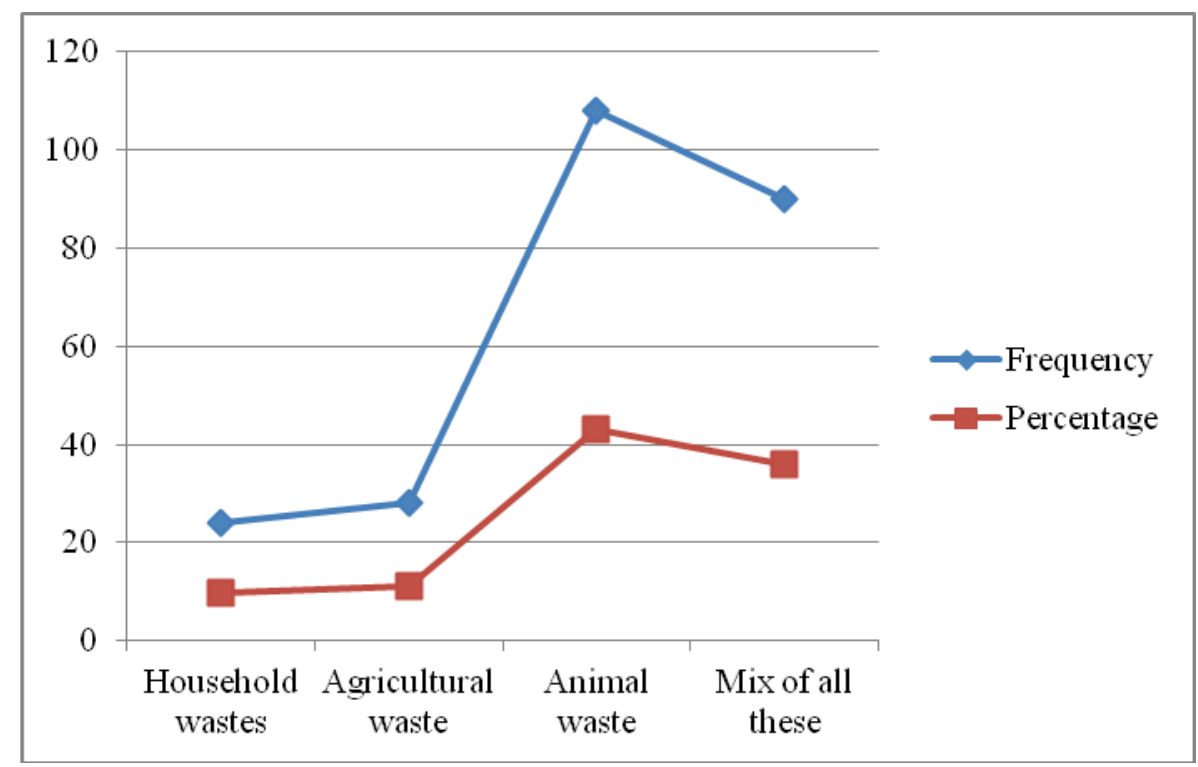

Figure 3: Raw material/waste used to produce organic manure

The results revealed that $9.6 \%$ of respondents used household waste such as food waste to produce manure; $11.2 \%$ used agricultural waste; $43.2 \%$ animal waste and $36 \%$ mixed both household and agricultural waste to produce organic manure. The dominance of animal waste over the other wastes can be linked to the wide availability of cattle among farmers. The management of organic waste by producing fertilizer has been experimented and reported for a long time. Bernal et al. (2009) reported that animal wastes had been traditionally collected for better processing and management through composting. Callaghan et al. (2002) revealed that the commercial compost product made from agricultural waste and treated with the organic manure (cattle slurries) is a safer alternative to chemical fertilizers for the best soil nutrients. Recycling of agricultural wastes is worthy of providing high-quality organic fertilizers.

\subsection{Attitude of farmers toward organic manure production}

Table 5: Gender and attitude of farmers toward organic manure production

\begin{tabular}{llllll}
\hline Gender & $\begin{array}{l}\text { I don't } \\
\text { like it }\end{array}$ & $\begin{array}{l}\text { I never } \\
\text { like it }\end{array}$ & I like it & $\begin{array}{l}\text { Definitely, I } \\
\text { like it }\end{array}$ & Total \\
\hline Male & 16 & 2 & 100 & 37 & 155 \\
& 10.32 & 1.29 & 64.52 & 23.87 & 100 \\
\hline Female & 16 & 1 & 40 & 38 & 95 \\
& 16.84 & 1.05 & 42.11 & 40 & 100 \\
\hline Total & 32 & 3 & 140 & 75 & 250 \\
& 12.8 & 1.2 & 56 & 30 & 100 \\
\hline
\end{tabular}

Pearson chi2(3) $=12.3737 \quad \mathrm{Pr}=\mathbf{0 . 0 0 6}$

The results indicated that $88.39 \%$ of male farmers showed a positive attitude towards organic manure production, while $11.61 \%$ showed a negative attitude. For female farmers, $82.11 \%$ had a positive attitude, while $17.89 \%$ had a negative attitude. The overall results showed that $86 \%$ of males and females positively enjoyed producing organic manure, while $14 \%$ had a negative attitude. The p-value at $1 \%$ showed that both males and females had a positive attitude regarding organic manure production, but 
women had a better attitude than men. This can be connected to the daily activities of women, whose aim is to ensure regular food supply and family health.

\section{Conclusion}

Municipal Solid waste contains a variety of both degradable and non-degradable wastes, of which the disposal to appropriate places has always been an issue, leading to environmental problems affecting public health. The easiest, cheapest and most environmentally safe method to manage the MSW is recycling by composting, to produce valuable manure and rich in plant nutrients. The farmers must take a leading role in organic manure production and make use of it for increasing crop productivity in view of a sustainable economy.

\section{Recommendations}

Firstly, there is a need to support farmers of Dakshina Kannada to increase their relevant knowledge and skills regarding the production and utilization of organic manure. secondly, the both farmer's and non farmer's communities must be trained on the solid waste management processes. Thirdly, both communities and government authorities must be involved in the waste recycling for a cleaner and safer environmental dimensions.

\section{References}

Abdoulaye, T., \& Sanders, J. H. (2005). Stages and determinants of fertilizer use in semiarid African agriculture: the Niger experience. Agricultural economics, 32(2), pp.167-179.

Annepu, R. K. (2012). Sustainable solid waste management in India. Columbia University, New York, 2(01).

Antonious, G. F. (2003). Impact of soil management and two botanical insecticides on urease and invertase activity. Journal of Environmental Science and Health, Part B, 38(4), pp.479-488.

Arancon, N. Q., Edwards, C. A., Atiyeh, R., \& Metzger, J. D. (2004). Effects of vermicomposts produced from food waste on the growth and yields of greenhouse peppers. Bioresource Technology, 93(2), pp.139-144.

Bernal, M. P., Alburquerque, J. A., \& Moral, R. (2009). Composting of animal manures and chemical criteria for compost maturity assessment. A review. Bioresource technology, 100(22), pp.5444-5453.

Callaghan, F. J., Wase, D. A. J., Thayanithy, K., \& Forster, C. F. (2002). Continuous co-digestion of cattle slurry with fruit and vegetable wastes and chicken manure. Biomass and bioenergy, 22(1), pp.71-77.

Carletto, C., Savastano, S., \& Zezza, A. (2011). Fact or artefact: the impact of measurement errors on the farm size-productivity relationship. The World Bank.

Chikezie, N. P., Chikaire, J., Osuagwu, C. O., Ihenacho, R. A., Ejiogu-Okereke, N., Oguegbuchulam, M. N., \& Obi, K. U. (2012). Factors constraining rural youths involvement in cassava production in Onuimo Local Government Area of Imo State, Nigeria. Global Advanced Research Journal of Agricultural Science, 1(8), pp.223-232.

Crano, W. D., Brewer, M. B., \& Lac, A. (2014). Principles and methods of social research. Routledge.

Du, Y., Feng, H., Zhang, K., Hu, L. F., Fang, C. R., Shen, D. S., \& Long, Y. Y. (2014). Role of iron in $\mathrm{H}_{2} \mathrm{~S}$ emission behavior during the decomposition of biodegradable substrates in landfill. Journal of hazardous materials, 272, pp.36-41.

Durbin, C. G. (2004). Effective use of tables and figures in abstracts, presentations, and papers. Respiratory care, 49(10), pp.1233-1237. 
Fageria, N. K. (2007). Green manuring in crop production. Journal of Plant Nutrition, 30(5), pp.691-719.

Garg, P., Gupta, A., \& Satya, S. (2006). Vermicomposting of different types of waste using Eisenia foetida: A comparative study. Bioresource technology, 97(3), pp.391-395.

Ginting, D., Kessavalou, A., Eghball, B., \& Doran, J. W. (2003). Greenhouse gas emissions and soil indicators four years after manure and compost applications. Journal of Environmental Quality, 32(1), pp.23-32.

Grewal, S. K., Rajeev, S., Sreevatsan, S., \& Michel, F. C. (2006). Persistence of Mycobacterium avium subsp. paratuberculosis and other zoonotic pathogens during simulated composting, manure packing, and liquid storage of dairy manure. Applied and environmental microbiology, 72(1), pp.565-574.

Inckel, M., de Smet, P., Tersmette, T., \& Veldkamp, T. (2005). The preparation and use of compost. $7^{\text {th }}$ edition. The Publisher Wageningen, Netherlands.

Kelly, V. A. (2006). Factors affecting demand for fertilizer in Sub-Saharan Africa. Agriculture and rural development discussion paper, 23, World Bank, Washington DC.

Kim, M. H., \& Kim, J. W. (2010). Comparison through a LCA evaluation analysis of food waste disposal options from the perspective of global warming and resource recovery. Science of the total environment, 408(19), pp.3998-4006.

Kucharski, J., Jastrzebska, E., Jastrzebska, E., Wyszkowska, J., Wyszkowska, J., Hlasko, A., \& Hlasko, A. (2000). Effect of pollution with diesel oil and leaded petrol on enzymatic activity of the soil. Zeszyty Problemowe Postepów Nauk Rolniczych, (472), pp.457-464.

Kumar, R., \& Yadav, S. (2011). Removal of pathogens during vermi-stabilization. J Environ Sci Tech, 4(6), pp.621-629.

Lal, R. (2015). Soil Carbon Sequestration in Agroecosystems of India. Journal of the Indian Society of Soil Science, 63(2), pp.125-143.

Lalande, R., Furlan, V., Angers, D. A., \& Lemieux, G. (1998). Soil improvement following addition of chipped wood from twigs. American journal of alternative agriculture, 13(3), pp.132-137.

Lim, S. L., Lee, L. H., \& Wu, T. Y. (2016). Sustainability of using composting and vermicomposting technologies for organic solid waste biotransformation: recent overview, greenhouse gases emissions and economic analysis. Journal of Cleaner Production, 111, pp.262-278.

Lim, S. L., Wu, T. Y., Lim, P. N., \& Shak, K. P. Y. (2015). The use of vermicompost in organic farming: overview, effects on soil and economics. Journal of the Science of Food and Agriculture, 95(6), pp.1143-1156.

Maity, T. K., \& Tripathy, P. (2004). Organic farming of vegetables in India: Problems and Prospects. Department of Vegetable Crops, Faculty of Horticulture, Bidhan Chandra Krishi Viswavidyalaya. Available at www. share. 4dev. info/kb/documents/2997. pdf.

Moore, P. A., Daniel, T. C., Gilmour, J. T., Shreve, B. R., Edwards, D. R., \& Wood, B. H. (1998). Decreasing metal runoff from poultry litter with aluminum sulfate. Journal of Environmental Quality, 27(1), pp.92-99.

Moral, R., Paredes, C., Bustamante, M. A., Marhuenda-Egea, F., \& Bernal, M. P. (2009). Utilisation of manure composts by high-value crops: Safety and environmental challenges. Bioresource Technology, 100(22), pp.5454-5460.

Morris, M., Kelly, V. A., Kopicki, R. J., \& Byerlee, D. (2007). Fertilizer use in African agriculture: Lessons learned and good practice guidelines. The World Bank. Agriculture and Rural development, 39037.

Okoboi, G., \& Barungi, M. (2012). Constraints to fertilizer use in Uganda: insights from Uganda Census of Agriculture 2008/9. Journal of Sustainable Development, 5(10), pp.99-113. 
Shitala, P. (2014). Solid Waste Management in the Metro Cities of India. Rizvi Institute of Management studies \& Research, 5(1), pp.92-101.

Stratton, M. L., \& Rechcigl, J. E. (1998). Organic mulches, wood products, and composts as soil amendments and conditioners. Handbook of Soil Conditioners. Marcel Dekker, New York, NY, 4395.

Sudharmaidevi, C. R., Thampatti, K. C. M., \& Saifudeen, N. (2017). Rapid production of organic fertilizer from degradable waste by thermochemical processing. International Journal of Recycling of Organic Waste in Agriculture, 6(1), pp.1-11.

Ukoje, J. A., \& Yusuf, R. O. (2013). Organic fertilizer: the underestimated component in agricultural transformation initiatives for sustainable small holder farming in Nigeria. Ethiopian Journal of Environmental Studies and Management, 6(6), pp.794-801.

Watts, D. B., Torbert, H. A., Prior, S. A., \& Huluka, G. (2010). Long-term tillage and poultry litter impacts soil carbon and nitrogen mineralization and fertility. Soil Science Society of America Journal, 74(4), pp.1239-1247.

Yip, C., Han, N. L. R., \& Sng, B. L. (2016). Legal and ethical issues in research. Indian journal of anaesthesia, 60(9), pp.684-688.

Zhang, P., Chen, X., Wei, T., Yang, Z., Jia, Z., Yang, B., ... \& Ren, X. (2016). Effects of straw incorporation on the soil nutrient contents, enzyme activities, and crop yield in a semiarid region of China. Soil and Tillage Research, 160, pp.65-72. 